\section{HUNTING RECORD OF ENDANGERED MARBLED CAT PARDOFELIS MARMORATA IN THE ZIRO VALLEY OF LOWER SUBANSIRI, ARUNACHAL PRADESH, INDIA}

\author{
K. Muthamizh Selvan ${ }^{1}$, Govindhan Veeraswami Gopi ${ }^{2}$, \\ Bilal Habib ${ }^{3}$ \& Salvador Lyngdoh ${ }^{4}$ \\ 1,2,3,4 Wildlife Institute of India, Post Box 18, Chandrabani, Dehradun, \\ Uttarakhand 248001, India \\ ${ }^{1}$ selvan@wii.gov.in, ${ }^{2}$ gopigv@wii.gov.in (corresponding author) \\ ${ }^{3}$ bh@wii.gov.in, ${ }^{4}$ salvador@wii.gov.in
}

Recently, we photo documented, for the first time, the occurrence of two rare felids, namely, the Marbled Cat Pardofelis marmorata and Asiatic Golden Cat Catopuma temminckii from a protected area in western Arunachal Pradesh (Lyngdoh et al. 2011). The Marbled Cat is distributed across the tropical forests of South East Asia. The Marbled Cat morphologically resembles the Clouded Leopard with a long tail, cloudlike pelage pattern, and elongated canines (Pocock 1932; Sunquist \& Sunquist 2002), however, there are considerable differences between the two species in skull morphology and the Marbled Cat along with the Asiatic Golden Cat and bay cats have been reported to have originated from a common lineage of bay cats (Pocock 1932; Johnson et al. 2006). This seemingly miniature version of the Clouded Leopard is mainly found in moist and mixed deciduous-evergreen tropical forest and in hill forests (Nowell \& Jackson 1996; Duckworth et al. 1999; Holden 2001; Grassman et al. 2005). The species is known to occur in China through Myanmar (Shepherd \& Nijman 2008), Thailand (Grassman \& Tewer 2000), Laos, Vietnam, Cambodia (Duckworth et al. 2005), and Malay
Peninsula (Alzan \& Sharma 2006 and Indonesia (IUCN 2010). There have been no confirmed records in neighbouring Bangladesh (Hearn et al. 2012). In India, this species is restricted to eastern Himalayan foothills especially Arunachal Pradesh (Duckworth et al. 2005;

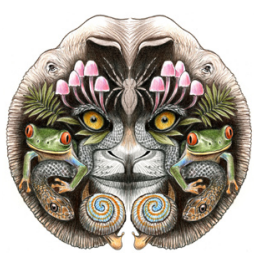

ISSN

Online 0974-7907 Print 0974-7893

\section{OPEN ACCESS} Mishra et al. 2006; Choudhury 2010) and Assam (Prater 1971).

Considering the low population densities and continuing loss of forested habitats, the IUCN has assessed the Marbled Cat as a Vulnerable species (Hearn et al. 2008). The Indian Wildlife Protection Act accords highest level of protection to this species by placing it under Schedule I (Anonymous 1972). Here we present a recent hunting record of Marbled Cats in Lower Subansiri District of Arunachal Pradesh.

As part of our study to assess the level of human wildlife conflict, extensive questionnaire surveys were conducted in three districts of Arunachal Pradesh, i.e., East Kameng, Papumpare and Lower Subansiri (Gopi et al. 2012). Local hunters, village headman ('Gambura') were interviewed for valuable information. During the survey, Pardofelis marmorata kill was encountered in Hija Village in Lower Subansiri District (Image 1). The fresh kill was made by a local hunter for Myoko festival which is celebrated by the indigenous Apatani community in the month of March/April every year (Dollo et al. 2009). Hija Village $27^{\circ} 34^{\prime} 37^{\prime \prime} N \& 93^{\circ} 49^{\prime} 28^{\prime \prime} E$ lies in the Ziro Valley that ranges in altitude from 1524 to $2738 \mathrm{~m}$ (Lyngdoh et al. 2010). This cat was hunted close to the Talley Valley Wildlife Sanctuary, which is around $15 \mathrm{~km}$ away from the Hija Village. The skin of this cat was

\footnotetext{
DOI: http://dx.doi.org/10.11609/JoTT.o3208.100 | ZooBank: urn:Isid:zoobank.org:pub:3BCFDA77-D00B-421A-AF0E-2D58D7E61F59

Editor: Shomita Mukherjee, Sálim Ali Centre for Ornithology and Natural History, Coimbatore, India. Date of publication: 26 January 2013 (online \& print)
} Manuscript details: Ms \# 03208 | Received 18 May 2012| Final received 01 December 2012 | Finally accepted 04 December 2012

Citation: Selvan, K.M., G.V. Gopi, B. Habib \& S. Lyngdoh (2013). Hunting record of endangered Marbled Cat Pardofelis marmorata in the Ziro Valley of Lower Subansiri, Arunachal Pradesh, India. Journal of Threatened Taxa 5(1): 3583-3584; doi:10.11609/JoTT.03208.100

Copyright: @ Selvan et al. 2013. Creative Commons Attribution 3.0 Unported License. JoTT allows unrestricted use of this article in any medium, reproduction and distribution by providing adequate credit to the authors and the source of publication.

Funding: The study was funded by the Department of Science and Technology, , Government of India (DST. No. SR/SO/AS-100/2007)

Competing Interest: None.

Acknowledgements: We are indebted to Mr. P.R. Sinha, Director of the Wildlife Institute of India and to Dr. V.B. Mathur, Dean of the Faculty of Wildlife sciences WII. Our most earnest acknowledgement must go to the department of Environment and forest, Government of Arunachal Pradesh and Tana Tapi DFO of pakke Tiger Reserve. We are grateful to Rubo Tahi driver in Ziro and our field assistant Manas Hazarika for their support in data collection. 


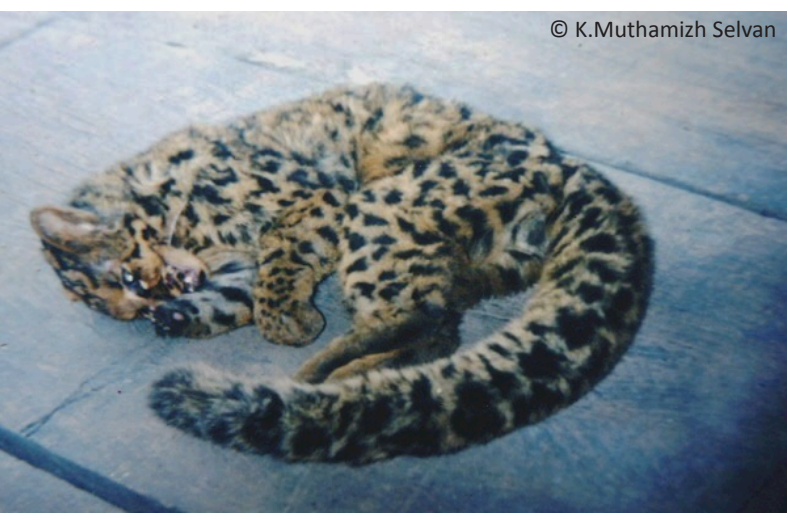

Image 1. Hunted Marbled Cat Pardofelis marmorata in Hija Village (13 April 2011), Lower Subansiri District, Arunachal Pradesh

also found in a neighboring Hong Village. The hunted Marbled Cat was used in the ceremony and blood of this cat was sacrificed to the deity for goodwill of their family and for ensuring a good harvest, protection from wildlife, disease and pest. The cat was captured by laying noose traps on trees, after seven hard days of camping in the forested areas. Hunters informed that apart from the Marbled Cat, Barking Deer Muntiacus muntjak and Black Bear Ursus thibetianus were also hunted in this sevenday period.

Major threats assessed by the IUCN for this species include rapid deforestation, illegal trade and indiscriminate snaring (Nowell \& Jackson 1996; Hearn et al. 2008). Hunting of this species is legally prohibited in India, Bangladesh, Cambodia, Nepal, Indonesia, Malaysia, Myanmar and Thailand (Jutzeler et al. 2010). However, enforcing the law in the northeastern states is a tricky issue, as most of the lands are under tribal ownership. Though hunting of wildlife is mainly done for subsistence and socio-cultural reasons in this region, the access to markets drive the hunters beyond their subsistence needs for additional income (Dollo et al. 2009; Gopi \& Dollo 2009).

With limited knowledge available on the distribution, status, population densities, prey selections, habitat preference and conservation requirements of this species, it is vital to initiate programmes to minimise the threats posed by hunting. There exists no information on the impacts and sustainability of such hunting practices on the species, survival in the long run. Though hunting is traditionally linked with the indigenous communities for centuries, it is vital to move on and this will require providing alternative resources to the communities, ensure education, health requirements, economics and development at par with other states. Unless, these are done, we will continue to lose our rare, threatened and endangered wildlife like marbled cats.

\section{REFERENCE}

Anonymous (1972). The Wild Life Protection Act, (1972). Professional Book Publishers, New Delhi.

Choudhury, A. (2010). Records of cats in Dihang-Dibang Biosphere reserve in North-eastern India. Catnews 53: 22-24

Dollo, M., G.V. Gopi, K. Teegalapalli \& K. Mazumdar (2010). Conservation of the Orange-bellied Himalayan Squirrel Dremomys lokriah using a traditional knowledge systems: a case study from Arunachal Pradesh, India. Oryx 1-4.

Duckworth, J.W., C.M. Poole, R.J. Tizard, J.L .Walston \& R.J. Timmins (2005). The Jungle Cat Felis chaus in Indochina: a threatened population of widespread and adaptive species. Biodiversity and Conservation 14: 1263-1280

Duckworth, J.W., R.E. Salter \& K. Khounboline (compilers) (1999). Wildlife in Lao PDR: 1999 status report. IUCN-The World Conservation Union / Wildlife Conservation Society / Centre for Protected Areas and Watershed Management, Vientiane.

Gopi, G.V., B. Habib, K.M. Selvan \& S. Lyngdoh (2012). Conservation of the endangered Asiatic Wild Dog Cuon alpinus in Western Arunachal Pradesh: linking ecology, ethnics and economics to foster better coexistence. Wildlife Institute of India, Dehradun DST Project Completion Report DST Project Completion Report TR-2012: 137pp.

Gopi, G.V. \& M. Dollo (2009). Land of apatanis. Sanctuary Asia XXIX(2): 60-65.

Grassman, L.I. Jr. \& M.E. Tewers (2000). Marbled Cat in north eastern Thailand. Catnews 33: 24.

Grassman, L.I. Jr., M.E. Tewes, N.J. Silvy \& K. Kreetiyutanont (2005). Ecology of three sympatric felids in a mixed evergreen forest in north-central Thailand. Journal of Mammalogy 86(1): 29-38.

Hearn, A., J. Sanderson, J. Ross, A. Wilting, S. Sunarto, J.A. Khan, S. Mukherjee \& L. Grassman (2008). Pardofelis marmorata. In: IUCN 2011. IUCN Red List of Threatened Species. Version 2011.2. <www. iucnredlist.org>. Downloaded on 18 May 2012.

Jutzeler, Y., Xie \& K. Vogt (2010). Marbled Cat. Catnews 5: 46-47.

Lyngdoh, S., K.M. Selvan, G.V. Gopi \& B. Habib (2011). First photographic evidences of two rare cats from Pakke Tiger Reserve, western Arunachal Pradesh. Current Science 101(10): 1284-1286.

Mishra, C., M. Madhusudan \& A. Datta (2006). Mammals of the high altitude of western Arunachal Pradesh, eastern Himalaya: an assessment of threats and conservation needs. Oryx 40: 29-35.

Nowell, K. \& P. Jackson (1996). Wild cats: status survey and conservation action plan. The World Conservation Union, Gland, Switzerland.

Pocock, R.I. (1932). The Marbled Cat (Pardofelis marmorata) and some other oriental species, with a definition of a new genus of the Felidae. Proceedings of the Zoological Society of London 1932: 741-766.

Prater, S.H. (1971). The Book of Indian Animals. Oxford University Press.

Shepherd, C.R. \& V. Nijman (2008). The wild cat trade in Myanmar. Selangor, Malaysia. TRAFFIC, 24pp.

Sunquist, M.E. \& F. Sunquist (2002). Wild Cats of The World. University of Chicago Press, Chicago, Illinois, 462pp. 